\title{
Collaboration among SMEs as a Mechanism for Innovation: An Empirical Study
}

\author{
Mário José Batista Franco
}

The interest for collaboration among small and mediumsized enterprises and innovation has been highlighted, in recent times, due to the acceleration of technological changes and to increasing international competitiveness. Many small firms, with rigid structures and weak entrepreneurial dynamics, experienced difficulties in becoming innovators. Some of these firms can adopt collaborative agreements because these relationships enable them to get the necessary innovative activities, know-how, and exploit opportunities, which they cannot achieve alone.

This study examines the motives for the formation of collaborative agreements in industrial Portuguese SMEs and presents some empirical evidence concerning collaboration as an important vehicle for the innovativeness of these small firms. The findings were based on a sample of 92 firms/collaborative agreements.

$\mathrm{F}$ aced with global economic competitiveness, the need for collaboration among small and mediumsized enterprises (SMEs), completed with innovation has become a subject of prime importance to governments, industry, and academics. Firms are reminded constantly that collaboration strategy (Jarillo 1990) and innovation (Chaharbaghi and Newman 1996) lie at the heart of competitive performance. Collaboration and innovation have been widely regarded as an important change process that can sustain business development in increasingly dynamic markets. In recent years, a large amount of literature has emerged on collaboration strategy (Franco 1995, 2001; Glaister and Buckley 1996; Volery 1996) and innovation (Pettitt 1990), but very little basic research has been conducted by industry recognizing that these two instruments can be related and they can contribute to international competitiveness. However, a recent study (Kaufman et al. 2000) explored the relationships among collaboration, technology, and innovation in SMEs manufacturers.

In fact, in a globally competitive marketplace, collaboration and innovation-new technologies, new skills, and new systems-are transforming the goals and practice of economic development. For Birchall et al. (1996), competitive pressures and market globalization have provided the inputs for innovation (i.e., creation, development, and introduction) of new product/services or a new procedure or process for business to benefit one or more of the stakeholders in an organization.
In this sense, González et al. (1997) argue that because firms must adapt themselves to a changing external environment, they need an aggressive innovation policy in order to convert innovation into competitive advantage. This circumstance has obliged firms to introduce innovation into their strategic plans, so they can attain the necessary competitiveness to operate in the current environment. To innovate there has to be a determination to achieve some results. Such a determination will then transform itself through creativity into a vision of the future where opportunities can be realized. The exploitation of these opportunities requires certain models and tools, the application of which will refocus the organization on new ways of working (Chaharbaghi and Newman 1996).

Due to their limited financial and human resources, some SMEs need to develop collaborative agreements with other firms, public institutions, and large corporations. Collaboration among SMEs can be a good strategy to overcome some of these constraints and to reinforce and improve the level of their innovation. As stressed by Celeste (1996), beginning in the 1980s, collaboration helped revitalize key industries. Now, a new generation of collaborative agreements is beginning, ones formed to focus on technology innovation. These relationships include university agreements, research institute agreements, collaborative research and development (R\&D) agreements, inward technology licensing, and, in certain instances, R\&D limited partnerships.

Collaboration encourages firms to maintain continual innovation and quality improvement needed to compete globally, and to strengthen market position. Industrial collaboration is almost unanimously considered vital to a firm's survival. Hausler et al. (1994) state that collaborative agreements are perceived as a major source of a nation's competitive strength and, according to Harrison (1997), firms have been encouraged to innovate so as to increase their competitiveness.

In this context, the theoretical framework of this study is to explore the developing literature about motives for collaboration formation and to analyse firms' innovative behavior, as well as to present some empirical evidence about these last two issues.

In this research, innovations are considered as a set of activities limited in space and time, and include new products, new processes, new organizational technologies, or new social methods. 


\section{Theoretical Framework}

\section{Collaboration among Firms for the Rapid Exploitation of Innovation}

Collaboration among firms has become a focal issue in the debate on industrial innovation. The ascent of collaborative agreements as a central topic in the literature on innovation has been accompanied by proposals for a redefinition of concept of innovation (Hausler et al.. 1994; Dutta and Weiss 1997). Evidence supporting an increasing need for collaborative agreements in industrial innovation processes has been provided by an increasing number of studies. According to Hausler et al. (1994), numerous empirical studies have revealed firms' motivations for participating in collaborative agreements.

In an economic environment where innovation tends to be increasingly costly and where the timing of market entry appears to be increasingly critical for the commercial success of innovations, collaboration strategy is seen as the most promising way to reduce the risks and costs associated with industrial R\&D activities (Hausler et al. 1994). As stressed by Kotabe and Swan (1995), global and increasingly key organizational forms are being created through collaborative agreements.

According to Rosenberg (1991) and Tushman (1977), new models must be able to incorporate notions such as feedback between scientific research, technical development, and production. In organizational terms, such "interactive" or "circular" models of innovation presume an institutional structure of innovation that is extremely variegated and involves a complex network of backward, forward, horizontal, and lateral relationships and linkages within and among firms and organizations such as universities (Hausler et al. 1994).

According to Celeste (1996), collaborative agreements formed to share the costs and benefits of new technology and operating methods, serve as important new tools for economic development. Technology and innovation are often the key drivers in the formation of business partnerships and collaboration, reflecting the parallel relationship between the institutional and the technological areas (Arias 1995).

As changes in an environment create possibilities for future innovations, Forrest (1990) states that collaborative agreements allow small firms to innovate in a timely manner, for often there is an optimal time to develop a new product.

Several authors have provided reasons for collaboration formation. An explanation for use of collaborative agreements stems from theories on how strategic behavior influences the competitive positioning of the firm (Kogut 1988). Harrigan (1985), Mariti and Smiley (1983), Porter and Fuller (1986), Contractor and Lorange (1988), and Glaister and Buckley (1996) explicitly consider a number of the motives for collaboration formation. Collaboration has a competitive use in that it could consolidate a firm's existing market position. Collaborative agreements also allow firms to diversify into attractive but unfamiliar business areas, thereby providing a less risky means of entering new markets.

The theoretical frameworks for the explanation of collaboration processes do not map neatly on to motives. According to Glaister and Buckley (1996), the mainstream economics approach treats the extension of the firm by collaborative agreements as a means to obtain economies of scale. Transaction cost explanations emphasize the use of collaboration as a means of reducing costs and the reduction of risks. Motives of organizational theory involve a transfer of technology and the suggestion from this body of theory is that international expansion is facilitated by cooperation. Collaboration among SMEs provides benefits from the exploitation of innovative activities, technology, or other skills transfer (Harrigan 1985). Contractor and Lorange (1988) and Forrest (1990) point out that, in general, collaborative agreements can be used to bring together complementary skills and talents which cover different aspects of the know-how needed in technology industries. As noted by Glaister and Buckley (1996), significant innovation is likely to result from the fusing of these complementary skills, a result which is unlikely to be achieved by one firm acting alone.

Although many small firms will opt for growth through collaboration, the choice of agreement is important. Effective linkages can occur throughout the innovation chain. These linkages help the firms overcome their weaknesses and build on their strengths. The choice of alliance must depend on the focus of the firm's overall growth strategy (Forrest 1990). For example, collaborations such as R\&D agreements, marketing/distribution agreements, outward technology licensing, or joint ventures are valid choices, but may not fit every company's business plan.

Based on collaboration strategy, small firms would be wise to choose those relationships which help to strengthen their core technologies, and develop others which assist in their market focus. According to Forrest (1990), managers recognize that collaboration is a key factor in a firm's competitiveness and, therefore, a basic factor in their generic strategies. A unilateral agreement is necessary whereby the skills of one firm can complement those of another.

In conclusion, SMEs can use a variety of collaborative agreements to develop and to sustain their technological competitiveness, facilitate the rapid exploitation of their innovation activities, and facilitate international expansion.

\section{Entrepreneurial Innovation and Firm's Size}

For innovation to become the goal of firms, it must first be understood. However, the concept of innovation has been 
defined in different ways. According to Chaharbaghi and Newman (1996), the difficulty is that there is no common perspective to link different studies. Innovation is viewed differently, emphasising different components such as marketing, technology, and organization.

For example, some researchers (Berry and Taggart 1994; Celeste 1996; Chaharbaghi and Newman 1996; Hauschildt 1992; Harrison 1997) have used innovation to describe the introduction and spread of new and improved products and processes in the economy and "technological innovation" to describe advances in knowledge. For Hyvarinen (1992), innovation is an invention used on a large scale to take economic advantage of it. One basic invention may lead to several innovations.

Early definitions of an innovation were developed for industrial purposes and they stressed the product and process. Later, the concept was widened to cover different innovations from everyday improvements to large organizational renewals based on different technologies.

According to most studies (Birchall et al. 1996; Harrison and Watson 1998; Hyvarien 1992; Lara 1990), the contribution of small firms to research and innovation has grown regularly and seems to be slightly higher than that of very large corporations, mainly because SMEs have shorter development cycles and are closer to the market. In fact, only very recently have researchers and managers suggested that small firms are able to manage their technological knowledge and their know-how in a more systematic way than larger companies.

There is a continuous discussion about the association between size and innovative capacity. Some researchers argue that bigger firms' dynamism is greater in this field. However, other authors assert that SME possesses appropriate characteristics for innovative activities (González et al. 1997).

The size-innovation relationship debate is well known. Traditionally, two opposing positions existed. On one hand, are those who, following the arguments of Schumpeter (1942), considered that large firms were more innovative. On the other hand, there were those who maintained that small firms were more open to the introduction of organizational changes. The flexibility of the SMEs, their simple organizational structure, low risk, and receptivity to changes, would be, according to González et al. (1997), essential features for enabling SMEs to be innovative, both within the organization and in the external market.

Recent studies have paid more attention to the contribution that small firms could make in the innovation field. According to Jones-Evans et al. (1996), studies show that technologically innovative SMEs in the United Kingdom have above-average growth rates with regard to assets and exports. Moreover, such companies tend to have low bankruptcy rates.

Some empirical studies have attempted to clarify the relationship between size and innovative capability, but without definitive conclusions. There is evident ambiguity regarding the role that the variable of size assumes with regard to the collaborative agreements and to the capability of firms to generate innovation. With a steady number of products, a large organization, a greater diversity of capabilities, better marketing channels, and economies of scale, larger firms are more innovative (Baldwing and Scott 1987). On the other hand, small firms have to be even more highly innovative to attract more attention and overcome their competitors' advantages in order to attract their customers, as suggested by Utterback and Abernathy (1975) and Kotabe and Swan (1995). These smaller, less integrated, and undefended firms with new technological innovations collaborate with established firms to gain access to the latter's complementary assets of reputation and distribution channels, customer bases, and possible acceptance as dominant design in subcategory markets.

It is wholly conceivable that the introduction of successful products by larger firms can be attributed to innovations created by SMEs. Large firms are in a more favorable position to learn and to imitate the production and distribution advantages of small firms (Miles and Snow 1978).

Finally, it is important to note that a firm's size, in itself, is neither an advantage nor a disadvantage. But each dimensional step involves a set of specific characteristics that, depending on the objective (innovative behavior), can represent benefits or obstacles.

\section{Objective, Hypotheses, and Methodology}

\section{Research Objective}

SMEs represent the major part of the Portuguese industrial sector. About 76.5 percent of firms have fewer than 10 employees and less than 0.2 percent have more than 500 . Some of these small firms are concentrated in traditional activities such as textiles and clothing manufacture. These SMEs are mainly labor intensive and tend not to diversify their products or markets.

In this sense, competitiveness depends on a firm's innovative capability and cooperation strategy. Therefore, this research identifies the main motives for collaboration formation and explores the relationship between a firm's size and innovative behavior in industrial Portuguese SMEs.

\section{Hypotheses}

Research concerning the motives to engage in collaborative agreements has examined the development process from a variety of different theoretical perspectives. According to Frankel and Whipple (1996) motives are important because they represent the participating firms' goals for the collaboration. As such, motives may form the basis for evaluating potential and actual attainment. Different motives imply different goals. 
Understanding the potential impact of those differences is only one of many factors that are important to the successful creation, implementation, and maintenance of an agreement. Research suggests that critical issue regarding collaborative agreements concerns the recognition of complementary motives. Such recognition requires careful design, development, and use of interorganizational structures and procedures to achieve the cooperation goals and objectives inherent in each firm's motives.

Theoretical frameworks developed in collaboration field suggest that the formation of collaborative agreements is an innovative attempt by a firm to manage and control uncertainty (Spekman and Kirti 1990). While such theoretical frameworks broadly characterize the underlying rational for a firm's entry into a collaborative agreement, they generally do not explicitly detail those motives.

In fact, the literature gives little indication a priori of what to expect in terms of the relative importance of a set of motivating factors for collaboration among firms' formation. Thus, this reasoning leads to the first hypothesis.

Hypothesis 1: Since motives for collaboration are often multidimensional, very complex and heterogeneous, it is possible to aggregate motives into several factors (dimensions) for collaboration among SMEs formation.

Some theoretical and empirical studies (Jones-Evans et al. 1996; González et al.1997; Riedle, quoted in Birchall et al. 1996) propose that there are differences between SMEs and large firms in their innovative behavior. Some of these studies point out that small firms behave in a different way than large ones. These previous studies conclude that the innovative strategy implanted by both types of firms is different and presuppose a homogeneous behavior of the SME with respect to the innovation. However, other studies (González et al. 1997; Hage and Aiken 1970; Thompson 1967) suggest that several characteristics of small firms make them more likely to introduce changes. Thus, size can play a role in the diversity of a firm's size, a mixture of large and small firms, and has been supported as most conducive to innovation. Finally, despite empirical studies that have attempted to clarify this relationship between size and innovation capability, they do not arrive at definitive conclusions.

The research does also not present explicitly this association, about firm size and the motives for collaboration formation, which leads to the second hypothesis.

Hypothesis 2: The relative importance of the motives for collaboration formation will vary with the firm's size. The dimension (factor) associated with innovative activities will also vary with this contingency variable.

\section{Methodological Aspects}

Sample and Data. In Portugal, there is no publicly available database about cooperative agreements because most of them are implicit (tacit or informal). In order to analyse the potential association between collaborative agreements in Portuguese SMEs (firms with less than 250 employees) and their innovative behavior, data were collected from a survey based on a database created in an empirical study (Franco 2001). In this previous research, a total of 627 questionnaires were administered in February 2000. After one reminder, 114 usable questionnaires were returned, representing an 18.3 percent response rate. This low response rate may be due to the fact that small firms find it more of a problem to reply to mail questionnaires than larger companies, especially when the subject is relatively new, as in this study. Another potential argument is that the managers in small firms would have only a limited amount of time to devote to the questionnaire and limited human resources. Note that, in this study, the data were only collected from the 92 questionnaires corresponding to SMEs.

To evaluate the main motives for collaboration formation, business owners were asked to respond to a set of statements on a five-point Likert scale (i.e., $1=$ "of no importance" to 5 = "of major importance"). ${ }^{1}$ Prior research indicated that ordinal classification of perception was a more realistic task for respondents than use of interval or ratio measures (Geringer 1991). It was also expected that managers would have only a limited amount of time to devote to the questionnaire, hence an easily understood Likert scale appeared to be more feasible than a potentially more precise but more complex scaling method. A fivepoint scale was adopted because it was felt that more numerous response categories would exceed the respondent's ability to discriminate, with the likelihood that "noise" rather than more precise data would result. See Table 2 for a complete list of collaborative motives.

Statistical Analysis. Based on statistical tools (frequency analysis, factor analysis, as well as multivariate analysis) and using the Statistical Package for Social Sciences (SPSS), the data collected were analyzed to provide an overview of collaboration and innovation variables. First, an approximation to the behavioral understanding of the collaboration and innovative firms was made from frequencies' analysis of the variables included in the survey. Second, results were obtained from a factor analysis of variables indicating the main motives perceived by the SMEs regarding collaboration. Finally, a one-way ANOVA (statistic F) was performed to identify some association between a firm's size and innovative motives.

Table 1 summarizes the methodological aspects and others used to validate the cooperation and innovation behavior in Portuguese firms. 


\begin{tabular}{|l|l|}
\hline \multicolumn{2}{|c|}{$\begin{array}{c}\text { Methodological Aspects Used } \\
\text { in the Empirical Research }\end{array}$} \\
\hline Fieldwork time & Cross-section \\
\hline Geographic focus & Portugal \\
\hline Industrial coverage & Manufacturing sector \\
\hline Firm's size & Small, medium, and large firms \\
\hline Units of analysis & Firm and agreements \\
\hline Sampling design & Convenience \\
\hline Initial sample size & $114 / 627$ (Response rate: 18.3\%) \\
\hline Final sample size & 92 SMEs/agreements \\
\hline Data collection & Mail survey (questionnaire) \\
\hline Date of research field & January to April 2000 \\
\hline Key informant & Top management (general)/manager \\
\hline Analysis & Statistical (univariate and multivariate) \\
\hline
\end{tabular}

\section{Findings and Discussion}

\section{Sample Characteristics}

The sample is composed of $92 \mathrm{SMEs}^{2}$ and presented some diversity with respect to size distribution. About 23 percent of the firms were medium-size and only six firms were micro-size (less than 10 employees). In the industrial sector, machines and equipment $(20.4 \%$ of the total), textile and clothing industry (10.4\%) were more representative. The localization of these firms was distributed in the following main areas: Aveiro (20.4\%), Lisbon (19.4\%), and Leiria (15.1\%). Regarding their juridical form, $\mathrm{S}$ Corporation ${ }^{3}$ was more representative (52 firms). Firms were an average of 26 years old, ranging between 1 and 119 years, and many of the SMEs (57.8\%) were family businesses.

\section{Main Motives for Collaboration Formation}

To determine the main firms' motivations for participating in collaborative agreements, firms were asked to value a set of variables (motives), which were later submitted to factor analysis.

The motivations for collaborative agreements, which are based on the mean measure of the importance of the motives, are shown in Table 2. For the full set of agreements, the mean is higher for the following motives: "entering new markets," "to improve the level of innovation," and "to share resources and competencies."

\begin{tabular}{|c|c|c|c|}
\hline \multicolumn{4}{|c|}{$\begin{array}{c}\text { Table } 2 \\
\text { Motivation for Collaborative Agreement Formation: } \\
\text { Motives Ranked by Mean Measure of Importance }\end{array}$} \\
\hline Survey Item/Motivation & Mean & $\begin{array}{l}\text { Standard } \\
\text { Deviation }\end{array}$ & $\begin{array}{c}\text { Number of } \\
\text { Firms }\end{array}$ \\
\hline Entering new markets & 3.761 & 1.152 & 92 \\
\hline To improve the level of innovation & 3.685 & 1.037 & 92 \\
\hline To share resources and competencies & 3.663 & 1.041 & 92 \\
\hline To create economies of scale & 3.533 & 1.032 & 92 \\
\hline To increase production capacity & 3.478 & 1.172 & 92 \\
\hline To improve the quality & 3.391 & 1.89 & 92 \\
\hline Facilitate international expansion & 3.337 & 1.102 & 92 \\
\hline To achieve some experience & 3.337 & 1.030 & 92 \\
\hline Technology transfer & 3.185 & 1.204 & 92 \\
\hline Risk sharing & 3.174 & 1.115 & 92 \\
\hline Faster payback on investment & 3.098 & 1.028 & 92 \\
\hline To foment learning process & 3.065 & 0.912 & 92 \\
\hline To improve the lead times & 2.902 & 1.112 & 92 \\
\hline To share superiors and techniques staffs & 2.696 & 0.958 & 92 \\
\hline To obtain financing & 2.641 & 1.033 & 92 \\
\hline
\end{tabular}




\begin{tabular}{|c|c|c|c|c|c|}
\hline \multicolumn{6}{|c|}{$\begin{array}{c}\text { Table } 3 \\
\text { Principal Components Factor Analysis of Collaboration Motivations in Firms }\end{array}$} \\
\hline Factors & $\begin{array}{l}\text { Factor } \\
\text { Loads }\end{array}$ & Eigenvalue & $\begin{array}{l}\% \text { Variance } \\
\text { Explained }\end{array}$ & $\begin{array}{c}\text { Cumulative } \\
\text { Percent }\end{array}$ & $\begin{array}{c}\text { Cronbach's } \\
\text { Alpha }\end{array}$ \\
\hline F1: Innovation and Organizational Learning & & 3.453 & 23.023 & 23.023 & 0.839 \\
\hline To improve the level of innovation & 0.810 & & & & \\
\hline To promote the learning process & 0.782 & & & & \\
\hline Technology transfer & 0.758 & & & & \\
\hline To share resources and competencies & 0.730 & & & & \\
\hline To improve the quality & 0.676 & & & & \\
\hline To achieve some experience & 0.512 & & & & \\
\hline F2: Development and Market Power & & 1.955 & 13.032 & 36.055 & 0.755 \\
\hline Facilitate international expansion & 0.863 & & & & \\
\hline Entering new markets & 0.799 & & & & \\
\hline F3: Resource Dependence & & 1.866 & 12.437 & 38.492 & 0.687 \\
\hline To obtain financing & 0.883 & & & & \\
\hline To share superiors and techniques staffs & 0.652 & & & & \\
\hline Faster payback on investment & 0.651 & & & & \\
\hline F4: Risks and Costs Sharing & & 1.644 & 10.962 & 59.454 & 0.666 \\
\hline To create economies of scale & 0.812 & & & & \\
\hline Risk sharing & 0.785 & & & & \\
\hline F5: To Reinforce Production Capacity & & 1.636 & 10.907 & 70.361 & 0.640 \\
\hline To increase production capacity & 0.881 & & & & \\
\hline To improve the lead times & 0.696 & & & & \\
\hline \multicolumn{6}{|c|}{$\begin{array}{ll}\text { Notes: } & \text { KMO measure of sampling adequacy }=0.746 \\
& \text { Bartlett Test of Sphericity: } 510,058 ; \mathrm{df}=105 ; \mathrm{p}<0.000 \\
\mathrm{Fi}(\mathrm{i}=1, \ldots, 5)-\text { Factors (dimensions) } \\
\text { Principal components factor analysis with varimax rotation }\end{array}$} \\
\hline
\end{tabular}

Other relatively highly ranked motives are "to create economies of scale" and "to increase production capacity." As shown in Table 2, the highest ranked motives are concerned with competitive positions in either new or existing markets, as well as in innovative activities.

As noted earlier, the 15 motives represent a number of overlapping perspectives. From the analysis factorial technique, five factors (dimensions) were produced which make good conceptual sense and explained 70.36 percent of the observed variance, as shown in Table 3. For each factor obtained from the factor analysis, a reliability analysis was also performed (Croncach's Alpha) to measure the internal consistency of each scale as a whole. Such an index, which varies between 0 and 1, measures the consistency among variables and those they are expected to measure. According to Malhotra (1993) and Hair et al. (1998), the closer the index is from 1, the better is the scale's internal consistency. Results obtained are displayed in the last column of Table 3. In general, we can observe that all the indexes are higher than 0.64, but not very close to 1 . According to the variables within each group, five factors were classified (see Table 3). The remainder of this section discusses the interpretation of each of these factors.

Innovation and Organizational Learning (Factor 1). This factor (dimension) includes motives associated with the development of resources and competencies in technology and innovation areas, with benefits in terms of quality. "To achieve some experience" was another motive for SMEs to collaborate. The experience is the main source of interorganizational learning. This factor aggregates also with the variable "to promote the learning process" as a reason related with collaboration formation. In fact, the motives that aggregate this first factor show the importance of activities' coordination and a very close relationship among firms. With this coordination and relationship among firms, know-how and accumulate experience sharing is easier.

Development and Market Power (Factor 2). This includes two motives/variables: "entering new markets" and "to facilitate international expansion." International collaboration can also be the easiest way to penetrate foreign markets. For SMEs, which lack international experience, initial overseas expansion is often likely to be a collabora- 
tive agreement. Contractor and Lorange (1988) argue that, in general, it is an expensive, difficult, and time-consuming business to establish a global organization and a significant international competitive presence. In fact, the move to new foreign markets and the development of either a multidomestic or global strategy can be facilitated by collaboration formation even for firms with considerable overseas experience.

Resource Dependence (Factor 3). When one firm collaborates, it can achieve resources not otherwise available. Small firms can have access to tangible resources such as financing and investments. In fact, investment sharing among several SMEs in cooperation projects can reduce the costs. With collaboration among the firm's strategic thinking, the required financing can be lowered through such collaboration. This entrepreneurial mechanism allows access to different resources and capabilities within the process. This dimension (factor) shows that to enter into a collaborative agreement can be a risky option compared with investing alone.

Risks and Costs Sharing (Factor 4). This factor includes variables associated with a low uncertainty in the current environment. For example, when high development costs of new products exist, a collaboration agreement can lessen the risk or at least help to minimize a possible failure. Another motive that includes this dimension is economies of scale. Despite economies of scale sometimes increasing the risk, according to Sousa (1997), it can constitute a way to reduce the risk by more efficient cost structures.

To Reinforce Production Capacity (Factor 5). This factor includes two variables related to the production area: (1) rationalization of material resources to increase the production level, and (2) to achieve flexibility and specialization. For Roig (1989), the main objectives that the firms achieve when they adopt collaborative agreements are an economy of these resources and the reduction of excesses in production processes. Cooperation allows a firm to concentrate on its resources and distinctive competencies and to achieve other resources in speciality areas.

To sum up, the findings show a high number of motives that firms can associate with collaboration strategy. However, factorial analysis allows us to conclude that the SMEs are motivated by factors associated with (1) innovation and organizational learning, (2) development and market power, (3) resource dependence, (4) risks and costs sharing, and (5) reinforce production capacity. So it should be stressed that these findings give statistical support for hypothesis 1 .

\begin{tabular}{|c|c|c|c|c|}
\hline \multicolumn{4}{|c|}{$\begin{array}{c}\text { Table } 4 \\
\begin{array}{c}\text { Motivation for Collaborative Agreement Formation: } \\
\text { Firm's Size }\end{array}\end{array}$} & \multirow{3}{*}{$\begin{array}{l}\text { Statistic } \\
\qquad\end{array}$} \\
\hline \multirow[t]{2}{*}{ Factors/Dimensions } & \multicolumn{3}{|c|}{ Firm's Size } & \\
\hline & Group & Mean & S. Deviation & \\
\hline Factor 1: & Less than 10 & -0.092 & 1.087 & \multirow{3}{*}{0.888 (n.s.) } \\
\hline Innovation and Organizational & $11-50$ & -0.046 & 1.101 & \\
\hline Learning & $51-250$ & 0.048 & 1.001 & \\
\hline \multirow{3}{*}{$\begin{array}{l}\text { Factor 2: } \\
\text { Development and Market Power }\end{array}$} & Less than 10 & 0.341 & 1.074 & \multirow[b]{3}{*}{0.657 (n.s.) } \\
\hline & $11-50$ & -0.064 & 0.804 & \\
\hline & $51-250$ & 0.008 & 1.134 & \\
\hline \multirow{3}{*}{$\begin{array}{l}\text { Factor 3: } \\
\text { Resource Dependence }\end{array}$} & Less than 10 & -0.119 & 1.055 & \multirow{3}{*}{0.557 (n.s.) } \\
\hline & $11-50$ & -0.104 & 1.061 & \\
\hline & $51-250$ & 0.107 & 0.952 & \\
\hline \multirow{3}{*}{$\begin{array}{l}\text { Factor 4: } \\
\text { Risks and Costs Sharing }\end{array}$} & Less than 10 & 0.496 & 0.233 & \multirow{3}{*}{0.358 (n.s.) } \\
\hline & $11-50$ & -0.120 & 0.843 & \\
\hline & $51-250$ & -0.003 & 1.152 & \\
\hline \multirow{3}{*}{$\begin{array}{l}\text { Factor 5: } \\
\text { To Reinforce Production Capacity }\end{array}$} & Less than 10 & -0.258 & 0.735 & \multirow{3}{*}{$0.063 *$} \\
\hline & $11-50$ & 0.291 & 0.953 & \\
\hline & $51-250$ & -0.198 & 1.023 & \\
\hline \multicolumn{5}{|c|}{$\begin{array}{l}\text { Notes: The mean for the factors is the mean of the factor scores } \\
{ }^{*} p<0.10 \quad \text { n.s.: No significant }\end{array}$} \\
\hline
\end{tabular}




\section{Firm's Size and Innovation Relationship}

As the five factors (dimensions) are not correlated with each other, each of these motives can be pursued independently. Thus, particular combinations of these factors can underlie joint venture formation. To investigate further the underlying nature of the motivation for this sample of agreements, the analysis was developed by considering the motives' factors in terms of a firm's size. For size variable reports the means and standard deviations of the five factors, the rank order of these dimensions (factors) and the appropriate test statistic for comparing differences in means (One-way ANOVA), is shown in Table 4.

The findings suggest that there is only significant difference (at the 0.10 level) in the means of the five factors. On the basis of the findings it can be argued that, in terms of percentage, firm size is not linked with motives for collaboration formation but rather with innovative activities. It should be stressed however that these findings give weak statistical support for hypothesis 2 .

\section{Conclusions}

In an environment where competition has become severe, where national boundaries have been broken down, and where technological leadership can be transitory, collaboration should be used as an important mechanism for small firms to become innovators. Because of their dynamic environment and the gaps between the various links needed to complete the innovation process, firms must, out of necessity, forge lateral "links" in the form of collaborative agreements.

The innovation process for small firms can be simplified and addressed in terms of the collaborative agreements. The role of collaboration among SMEs, which has been discussed, and how they relate to the completion of the innovation process, has been an important mechanism for firms to achieve a higher level of innovation.

However, based on the findings obtained in this study, we can conclude that there are several motives that firms can adopt for collaborative agreements, including innovation. On the basis of these findings, it can be argued that small firms are linking up with other firms to pursue innovative activities at lower cost and to gain from the technological know-how of the partner. However, the empirical evidence does not confirm the size-collaboration-innovation relationship. The statistical test used indicates that the relative importance of the motivating factors do not vary significantly with a firm's size. So, this debate about a firm's size and collaboration and innovation behavior is still open. Further investigation into these two features would provide a deeper understanding of collaboration and innovation linkages.

Finally, we suggest that entrepreneurs adopt collaboration as an alternative strategy. It could be useful to put together more and more of these small firms to improve their level of innovation. From this study, it can be seen that for SMEs to develop and sustain their technological competitiveness and facilitate the rapid exploitation of their innovativeness, they should use a variety of collaborative agreements.

\section{Endnotes}

1. A " 3 " corresponds to "indifferent" and not "a mean importance."

2. One collaborative agreement was considered in each firm.

3. "S" Corporation is different from corporations due to the limited capital permitted by law (5.000 €contrasted to $50.000 €$ ) and the minimum number of partners (two versus five).

\section{References}

Arias, J. T. 1995. Do networks really foster innovation? Management Decision 33, 9: 52-56.

Baldwing, W. L., and J. Scott. 1987. Market structure and technological change. Chur, Switzerland, and New York: Harwood Academic Publishers.

Berry, M. M., and J. H. Taggart. 1994. Managing technology and innovation: A review. R\&D Management 24, 4: 341-353.

Birchall, D. W., J. J. Chanaron, and K. Soderquist. 1996. Managing innovation in SMEs: A comparison of companies in the UK, France and Portugal. International Journal of Technology Management 12, 3: 291-305.

Celeste, R. F. 1996. Strategic alliances for innovation: Emerging models of technology-based twenty-first century economic development. Economic Development Review (Winter): 4-8.

Chaharbagni, K., and V. Newman. 1996.) Innovating: Towards an integrated learning model. Management Decision. 34, 4: 5-13.

Contractor, F., and P. Lorange. 1988. Why should firms cooperate? In F. Contractor and P. Lorange, eds., Cooperative strategies in international business. Lexington, MA: Lexington Books, pp. 3-18. 
Dutta, S., and A. M. Weiss. 1997. The relationship between a firm's level of technological innovativeness and its pattern of partnership agreements. Management Science 43, 3 (March): 343-356.

Forrest, J. E. 1990. Strategic alliances and the small technology-based firm. Journal of Small Business Management (July): 37-45.

Franco, M. J. 1995. A cooperação entre empresas como meio de redimensionamento e reforço da competitividade das PME: O caso da região da Beira interior. Unpublished Master Dissertation, University of Beira Interior, Portugal.

Franco, M. J. 2001. The cooperation process in Portuguese firms: Formation, implementation and development. Doctoral Thesis. University of Beira Interior, Portugal.

Frankel, R., and J. S. Whipple. 1996. Alliance formation motives: A comparison of international perspectives. The International Journal of Logistics Management 7, 2:19-31.

Geringer, J. M. 1991. Strategic determinants of partner selection criteria in international joint ventures. Journal of International Business 22, 1: 41-62.

Glaister, K. W., and P. J. Buckley. 1996. Strategic motives for international alliance formation. Journal of Management Studies 33:3 (May): 301-332.

González, A., J. J. Jimènez, and F. J. Sáez. 1997. SME's innovative behavior: An empirical study. Internal Paper of the University of Castilla-La Mancha, Albacete, Spain.

Hage, J., and M. Aiken. 1970. Social change in complex organizations. New York: Randon House.

Hair, J. F., R. E. Anderson, R. L. Tatham, and W. C. Black. 1998. Multivariate data analysis, 5th ed. New Jersey: Prentice Hall.

Harrigan, K. R. 1985. Strategies for joint ventures. Lexington, MA: Lexington Books.

Harrison, N. J. 1997. Trends in innovation management: A global perspective. Conference proceedings in Western Decision Sciences Institute. 26th Annual Meeting, Hawaii, March 25-29.

Harrison, N. J., and T. Watson. 1998. The focus for innovation in small and medium service enterprises. Conference proceedings of Western Decision Sciences Institute. 27th Annual Meeting, Reno NV, April 7-11.

Hauschildt, J. 1992. External acquisition of knowledge for innovations-A research agenda. R\&D Management 22, 2 : 105-110.

Hausler, J., H. W. Hohn, and S. Lutz. 1994. Contingencies of innovative networks: A case study of successful interfirm R\&D collaboration. Research Policy (June): 47-66.

Hyvarinen, L. 1992. Innovativeness and its indicators in small- and medium-sized industrial enterprises. International Small Business Journal 9, 1: 65-77.

Jarillo, J. C. 1990. Research notes and communications: Comments on 'transaction costs and networks. Strategic Management Journal 11: 497-49.

Jones-Evans, D., P. Heydebreck, M. Lindqvist, E. Autio, and M. Fontes. 1996. Technology, innovation and enterprise-The European experience. Workshop at the ICSB 41st World Conference, June 17-19, Stockholm.

Kaufman, A., C. H. Wood, and G. Therely. 2000. Collaboration and technology linkages: A strategic supplier typology. Strategic Management Journal 21, 6: 649-663.

Kogut, B. 1988.) Joint ventures: Theoretical and empirical perspectives. Strategic Management Journal 9: 319-332.

Kotabe, M., and K. S. Swan. 1995. The role of strategic alliances in high-technology new product development. Strategic Management Journal 16: 621-636.

Lara, J. L. 1990. The contribution of small firms to invention and innovation. Discussion paper for the European Doctoral Programme in Entrepreneurship and Small Business Management, Universitat Autónoma de Barcelona, Spain.

Malhotra, N. K. 1993. Marketing research: An applied orientation. New Jersey: . Prentice-Hall.

Mariti, P., and R. H. SMILEY. 1983. Cooperative agreements and the organization of industry. The Journal of Industrial Economics XXX, 4 (June): 437-451.

Miles, R. E., and C. C. Snow. 1978. Organizational strategy, structure, and process, McGraw-Hill Book Company. 
Pettitt, S. J. 1990. Entrepreneurship in tourism: Developing a model of innovation potential. Conference Proceedings of Small Business Institute Director's Association: Changing Profiles: Challenges and Opportunities for NonTraditional Small Business Owners, Employees, and Markets. Houston, TX: February 15-8.

Porter, M. E., and M. B. Fuller. 1986. Coalitions and global strategy. In Michael E. Porter, ed., Competition in global industries. Boston MA: Harvard Business School Press, pp. 315-343.

Roig, B. 1989. Estrategias cooperatives. Economía Industrial, 266 (March-April): 77-85.

Rosenberg, N. 1991. Critical issues in science policy research. Science and Public Policy 18: 335-346.

Schumpeter, J. 1942. Capitalism, socialism, and democracy, New Cork: Harper and Brothers (Harper Colophon ed. 1976).

Spekman, R.E., and S. Kirti. 1990. Toward a conceptual understanding of the antecedents of strategic alliances. Marketing Science Institute (August): 90-114.

Sousa, V. D. 1997. Alianças estratégicas: Empresas Portuguesas no contexto internacional. Unpublished Master Dissertation, University of Minho, Portugal.

Thompson, V. 1967. Bureaucracy and innovation. Administrative Science Quarterly (June).

Tushman, M. L. 1977. Communication across organizational boundaries: Special boundary roles in the innovation process. Administrative Science Quarterly 22: 587-605.

Utterback, J. M., and N. J. Albernathy. 1975. A dynamic model of product and process innovation. Omega 36: 639-656.

Volery, T. 1996. La coopération inter-entreprises: Le Cas des Petites et Moyennes Entreprises Suisses, Doctoral Thesis, Fribourg University.

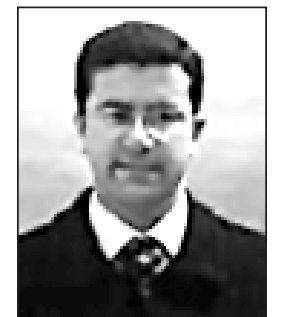

MÁrio J. B. Franco (mfranco@fenix.ubi.pt) is a professor of entrepreneurship and SMEs administration in the Department of Management and Economics at the Beira Interior University, Portugal. He received his Ph.D. in management from Beira Interior University in 2002. In 1997, He was a doctoral candidate and participated in the European Doctoral Programme in Entrepreneurship and Small Business Management in Spain and Sweden. His research focuses on strategic alliances, innovation, and creation of firms. He is also member of a Research Unit (NECE) and is currently involved in some research projects about SMEs. 